\title{
Seasonal characterization of CDOM for lakes in semiarid regions of Northeast China using excitation-emission matrix fluorescence and parallel factor analysis (EEM-PARAFAC)
}

\author{
Ying Zhao ${ }^{1}$, Kaishan Song ${ }^{1}$, Zhidan Wen ${ }^{1}$, Lin $\mathrm{Li}^{2}$, Shuying Zang ${ }^{3}$, Tiantian Shao ${ }^{1}$, Sijia $\mathrm{Li}^{1}$, and Jia Du \\ ${ }^{1}$ Northeast Institute of Geography and Agroecology, Chinese Academy of Sciences, Changchun, Jilin 130102, China \\ ${ }^{2}$ Department of Earth Sciences, Indiana University-Purdue University, Indianapolis, IN, USA \\ ${ }^{3}$ College of Geographical Science, Harbin Normal University, Harbin, China \\ Correspondence to: Kaishan Song (songks@iga.ac.cn)
}

Received: 28 October 2014 - Published in Biogeosciences Discuss.: 15 April 2015

Revised: 24 February 2016 - Accepted: 28 February 2016 - Published: 17 March 2016

\begin{abstract}
The seasonal characteristics of fluorescent components in chromophoric dissolved organic matter (CDOM) for lakes in the semiarid region of Northeast China were examined by excitation-emission matrix (EEM) spectra and parallel factor analysis (PARAFAC). Two humic-like (C1 and $\mathrm{C} 2$ ) and protein-like (C3 and $\mathrm{C} 4)$ components were identified using PARAFAC. The average fluorescence intensity of the four components differed under seasonal variation from June and August 2013 to February and April 2014. Components 1 and 2 exhibited a strong linear correlation ( $\left.R^{2}=0.628\right)$. Significantly positive linear relationships between CDOM absorption coefficients $a(254)\left(R^{2}=0.72\right.$, $0.46, p<0.01), a(280)\left(R^{2}=0.77,0.47, p<0.01\right), a(350)$ $\left(R^{2}=0.76,0.78, p<0.01\right)$ and $F_{\max }$ for two humic-like components ( $\mathrm{C} 1$ and $\mathrm{C} 2$ ) were exhibited, respectively. A significant relationship $\left(R^{2}=0.930\right)$ was found between salinity and dissolved organic carbon (DOC). However, almost no obvious correlation was found between salinity and EEM-PARAFAC-extracted components except for C3 $\left(R^{2}=0.469\right)$. Results from this investigation demonstrate that the EEM-PARAFAC technique can be used to evaluate the seasonal dynamics of CDOM fluorescent components for inland waters in the semiarid regions of Northeast China, and to quantify CDOM components for other waters with similar environmental conditions.
\end{abstract}

\section{Introduction}

Dissolved organic matter (DOM), a heterogeneous mixture of humic acids, proteins and carbohydrates, plays an important role in aquatic ecosystems (Zhang et al., 2010). Chromophoric dissolved organic matter (CDOM), the colored fraction of DOM, absorbs light energy in the ultraviolet (UV) and visible region of the spectrum and inhibits the propagation of UV radiation. CDOM in waters also affects the transport and bio-availability of materials such as trace metals and other pollutants (Song et al., 2013), so it can be used as a proxy of water quality. In natural waterbodies, CDOM originates from the degradation of plant materials and other organisms and terrestrially imported substances, which varies in time and space and is controlled by its structure and composition (Stedmon et al., 2003). CDOM is compositionally complex, making it difficult to isolate hydrophobic from hydrophilic acids using Amberlite XAD ionexchange resins (Aiken et al., 1992; Spencer et al., 2010). Nonetheless, some optically active components of CDOM can emit fluorescence after absorbing light at certain wavelengths (Zhang et al., 2010); therefore, fluorescence spectroscopic techniques can be used to provide detailed information about the source and concentration of CDOM. Traditional fluorescence techniques, including fluorescence emission spectrometry and synchronous fluorescence scanning, applied to examine CDOM components have the drawback that the output was restricted to a linear scan (Hudson et al., 2007). 
Recently, excitation-emission matrix (EEM) fluorescence spectroscopy has been applied to identify CDOM components because of its ability to produce synchronous scan spectra in the form of contours (Stedmon et al., 2003; Zhang et al., 2010). EEM spectroscopy is considered the most effective technique for studying the composition of fluorophores given its high selectivity and sensitivity to CDOM in water columns (Zhang et al., 2010). In recent years, EEM spectroscopy has been widely used to investigate the dynamics of marine, freshwater and ice meltwater ecosystems as well as snowmelt water (Barker et al., 2006, 2009, 2010, 2013; Coble, 2007; Fellman al., 2010; Guo et al., 2010; Hudson et al., 2007; Stedmon et al., 2007). Moreover, the EEM spectroscopy can also be used to distinguish allochthonous and autochthonous CDOM sources in aquatic environments (Coble et al., 1998; Mayer et al., 1999; Yamashita et al., 2008, 2010; Zhang et al., 2013). Based on the peak positions in the EEM, two main fluorescent components, i.e., humiclike and protein-like substances, have been identified and investigated (Del Castillo et al., 1999; Jaffé et al., 2004). However, overlapped fluorophores of CDOM EEM could make this traditional "peak-picking" method unreliable to evaluate CDOM dynamics in aquatic ecosystems (Coble, 1996; Stedmon et al., 2003). Recently, the combined EEM-PARAFAC (parallel factor analysis) technique has been shown to effectively decompose EEM of CDOM into independent fluorescent components and assess the source of CDOM and relationships with other water quality parameters. A number of investigators have used EEM-PARAFAC to characterize DOM in freshwater and marine aquatic environments (Borisover et al., 2009; Cory et al., 2005; Guo et al., 2010; Stedmon et al., 2003; Stedmon and Markager, 2005; Yamashita, 2008; Zhang et al., 2010, 2011, 2013). Stedmon et al. (2003) introduced PARAFAC and identified five distinct DOM components for a Danish estuary and its catchment. In coastal environments, Yamashita et al. (2008) reported on seven components using the combined EEMPARAFAC technique and assessed the dynamic of individual fluorophores and their relationship with salinity in Ise Bay. Zhang et al. (2011) also found three different components by PARAFAC modeling and analyzed the correlations between the fluorescent components and absorption coefficients of CDOM for Lake Tianmu and its catchment.

The Songnen Plain is a fluvial plain with semiarid climate, in which many fresh and brackish waters are distributed according to its geomorphological characteristics (Song et al., 2013). Dissolved organic carbon (DOC) characteristics of these fresh and brackish waters across the Songnen Plain have been studied by Song et al. (2013); the results indicated that a huge amount of DOC was stored in these waters. In particular, brackish waters would exhibit high average DOC concentrations and significantly contributed to the carbon budget to inland waters (Duarte et al., 2008; Song et al., 2013; Tranvik et al., 2009). However, little study has been done on the detailed information of DOC sources for these waters in the Songnen Plain. Therefore, it motivated us to investigate the components in CDOM for both fresh and brackish waters in the semiarid region. In the present study, the absorption and fluorescence of CDOM were determined for the water samples collected from seven lakes in the western part of the province of Jilin, which varied in different seasons. The specific objectives of this study are to (1) characterize CDOM components contained in these lakes using the EEM and their origins through the EEM-PARAFAC method; (2) assess the dynamic of individual fluorescent components of CDOM under seasonal variation; and most importantly (3) link CDOM fluorescence intensities, absorption coefficients, DOC concentrations and salinity to each other, in order to establish proxies for CDOM bioavailability and photoreactivity in waters.

\section{Materials and methods}

\subsection{Lakes and water sampling}

The waterbodies investigated in this study were located in the western part of Jilin, which belongs to the semiarid part of the Songnen Plain (Song et al., 2013). Two groups of lakes were investigated, i.e., the Chagan lake group and the Yuelianghu lake group. The Chagan lake group is made up of Lake Chagan (CGL), Xinmiaopao (XMP), Xindianpao (XDP) and Kulipao (KLP). The Yuelianghu lake group mainly includes Lake Yueliang (YLL), Talahong (TLH) and Xinhuangpao (XHP) (Fig. 1). The two groups are about $60 \mathrm{~km}$ away from each other, each of which includes both fresh and brackish waters. The primary economic value for these lakes is fisheries, agricultural irrigation and recreation. The average annual precipitation is about $391 \mathrm{~mm}$, but the average evaporation is up to $1790 \mathrm{~mm}$, resulting in water scarcity. Due to the area dominated by saline-alkali soil, the rainfall flush and agricultural catchment land use can result in an increase of lake salinities. These seven lakes are endowed with similar geological, hydrological and climatic settings; thus we presume that similar processes may control the CDOM components. In order to characterize the CDOM fluorescent components under seasonal variation using EEM-PARAFAC, 67 water samples were collected from the surface of the seven lakes in $1 \mathrm{~L}$ acid-cleaned plastic bottles during four field campaigns in June and August 2013 as well as in February and April 2014, respectively. These samples were collected during the ice-covering period using an ice drilling auger. The under-ice surface water came up when a hole was drilled in the ice layer by the auger. The ice shavings were collected in plastic bags and the under-ice surface water was collected in plastic bottles. The collected samples were held on ice and immediately transported to the laboratory in the city of Changchun in Jilin within 3-5h. In the laboratory, these samples were filtered within $24 \mathrm{~h}$ and then kept at $4{ }^{\circ} \mathrm{C}$ until analysis within 2 days. Latitude and longitude of each 
sample location were recorded in situ using a Trimble Global Positioning System (GPS).

\subsection{Analytical procedures}

To characterize the basic parameters of water quality, salinity was measured by a DDS-307 electrical conductivity meter in the laboratory. Salinity was expressed on the basis of the UNESCO practical salinity unit. The $\mathrm{pH}$ was measured using a PHS-3C $\mathrm{pH}$ meter at room temperature $\left(20 \pm 2{ }^{\circ} \mathrm{C}\right)$ in the laboratory. Water turbidity was determined using the Shimadzu UV-2600PC UV-visible dual beam spectrophotometer with matching $3 \mathrm{~cm}$ quartz cells at room temperature $\left(20 \pm 2^{\circ}\right)$ with Milli-Q water as the reference (UV Talk Letter, 2013). To determine DOC concentrations, water samples were filtered through $0.45 \mu \mathrm{m}$ filters and then measured using a Shimadzu TOC-5000 analyzer and a $1.2 \%$ Pt on silica catalyst at $680^{\circ} \mathrm{C}$. Potassium hydrogen phthalate was used as a reference. The reproducibility of the analytical procedure was within 2-3\% for the current study (APHA/AWWA/WEF, 1998; Song et al., 2011).

\subsection{Absorption measurement}

In the laboratory, all the samples were filtered at low pressure, first through a precombusted Whatman GF/F filter $(0.7 \mu \mathrm{m})$, and then through a prerinsed $25 \mathrm{~mm}$ Millipore membrane cellulose filter $(0.22 \mu \mathrm{m})$ into glass bottles. Absorption spectra of the samples were measured between 200 and $800 \mathrm{~nm}$ at $1 \mathrm{~nm}$ increments using the Shimadzu UV2600PC UV-visible dual beam spectrophotometer with a $1 \mathrm{~cm}$ quartz cuvette and Milli-Q water as a reference. The absorption coefficient $a_{\mathrm{CDOM}}$ was calculated from the measured optical density (OD) of the sample using Eq. (1):

$a_{\mathrm{CDOM}}(\lambda)=2.303\left[\mathrm{OD}_{(\lambda)}-\mathrm{OD}_{(\text {null })}\right] / \gamma$,

where $\gamma$ is the cuvette path length $(0.01 \mathrm{~m})$ and the factor 2.303 converts from base 10 to base natural logarithm transformation. Some fine particles possibly remained in the filtered solution (Babin et al., 2003; Bricaud et al., 1995); therefore it was necessary to correct for scattering by fine particles and in this case, $\mathrm{OD}_{\text {(null) }}$ is the average optical density over 740-750 $\mathrm{nm}$ where the absorbance of CDOM can be assumed to be zero.

A CDOM absorption spectrum $\left(a_{\mathrm{CDOM}}(\lambda)\right)$ can be expressed as an exponential function (Babin et al., 2003; Bricaud et al., 1995):

$a_{\mathrm{CDOM}}\left(\lambda_{i}\right)=a_{\mathrm{CDOM}}\left(\lambda_{\mathrm{r}}\right) \exp \left[-S\left(\lambda_{i}-\lambda_{\mathrm{r}}\right)\right]$,

where $a_{\mathrm{CDOM}}\left(\lambda_{i}\right)$ is the CDOM absorption at a given wavelength $\lambda_{i}, a_{\mathrm{CDOM}}\left(\lambda_{\mathrm{r}}\right)$ is the absorption estimate at the reference wavelength $\lambda_{\mathrm{r}}(440 \mathrm{~nm})$ and $S$ is the spectral slope of the CDOM absorption. According to Helms et al. (2008), $S$ is calculated by fitting a linear model to the data over a wavelength range of 275 to $295 \mathrm{~nm}(S 1)$ or 350 to $400 \mathrm{~nm}(\mathrm{~S} 2)$.
To eliminate the inter-laboratory variability, the slope ratio $S_{\mathrm{R}}=S 1 / S 2$ is defined to indicate the molecular weight and photobleaching of CDOM (Helms et al., 2008; Zhang et al., 2010).

\subsection{Three-dimensional fluorescence measurement}

The EEM analysis of CDOM was conducted using a Hitachi F-7000 fluorescence spectrometer (Hitachi HighTechnologies, Tokyo, Japan) with a 700-voltage xenon lamp. The scanning ranges were $200-450 \mathrm{~nm}$ for excitation, and 250-500 $\mathrm{nm}$ for emission. Readings were collected in the ratio mode at $5 \mathrm{~nm}$ intervals for excitation, and at $1 \mathrm{~nm}$ intervals for emission, using a scanning speed of $2400 \mathrm{~nm} \mathrm{~min}^{-1}$. The band passes were $5 \mathrm{~nm}$ for both excitation and emission. A Milli-Q water blank of the EEM was subtracted to eliminate the water Raman scatter peaks (McKnight et al., 2001; Stemdon et al., 2003; Zhang et al., 2010, 2011).

The inner-filter effect, which results from reabsorption and excitation of the fluorescence itself, can reduce the fluorescence intensity by $5 \%$ (Larsson et al., 2007; McKnight et al., 2001). In order to eliminate the inner-filter effect, the EEM was corrected for absorbance by multiplying each value in the EEM by a correction factor based on the assumption that the average path length of absorption of the excitation and emission light is one half length of the cuvette (McKnight et al., 2001; Zhang et al., 2010). The correction function is expressed as follows:

$F_{\text {corr }}=F_{\text {obs }} \times 10^{\left(A_{\mathrm{ex}}+A_{\mathrm{em}}\right) / 2}$,

where $F_{\text {Corr }}$ and $F_{\text {obs }}$ are the corrected and uncorrected fluorescence intensities and $A_{\mathrm{ex}}$ and $A_{\mathrm{em}}$ are the absorbance values at the respective excitation and emission wavelengths.

The measured fluorescence intensity is dependent on the concentration of the dissolved fluorophores in waterbodies. Finally, the fluorescence intensities of all samples' EEMs were normalized to the area under the Milli-Q water Raman peak $(\lambda \mathrm{ex}=350 \mathrm{~nm}, \lambda \mathrm{em}=371-428 \mathrm{~nm})$ measured daily (Lawaetz and Stedmon, 2009). The contour figures of the EEMs were plotted using the MATLAB 10.0 software package (MathWorks, Natick, Massachusetts, United States).

\subsection{PARAFAC modeling}

PARAFAC, a three-way method, is applied to divide the CDOM fluorescence into separate fluorescent signals (Andersen and Bro, 2003; Stedmon and Bro, 2008). According to Stedmon and Bro (2008), a similar PARAFAC analysis is carried out in the present study using the DOMFluor toolbox in MATLAB with the "N-way toolbox for MATLAB" (Andersson and Bro, 2000). Before PARAFAC modeling, the excitation wavelengths from 200 to $220 \mathrm{~nm}$ and the emission wavelengths from 250 to $300 \mathrm{~nm}$ were deleted because of their poor quality. In order to remove the effect of Rayleigh scatter on PARAFAC modeling, the miss- 


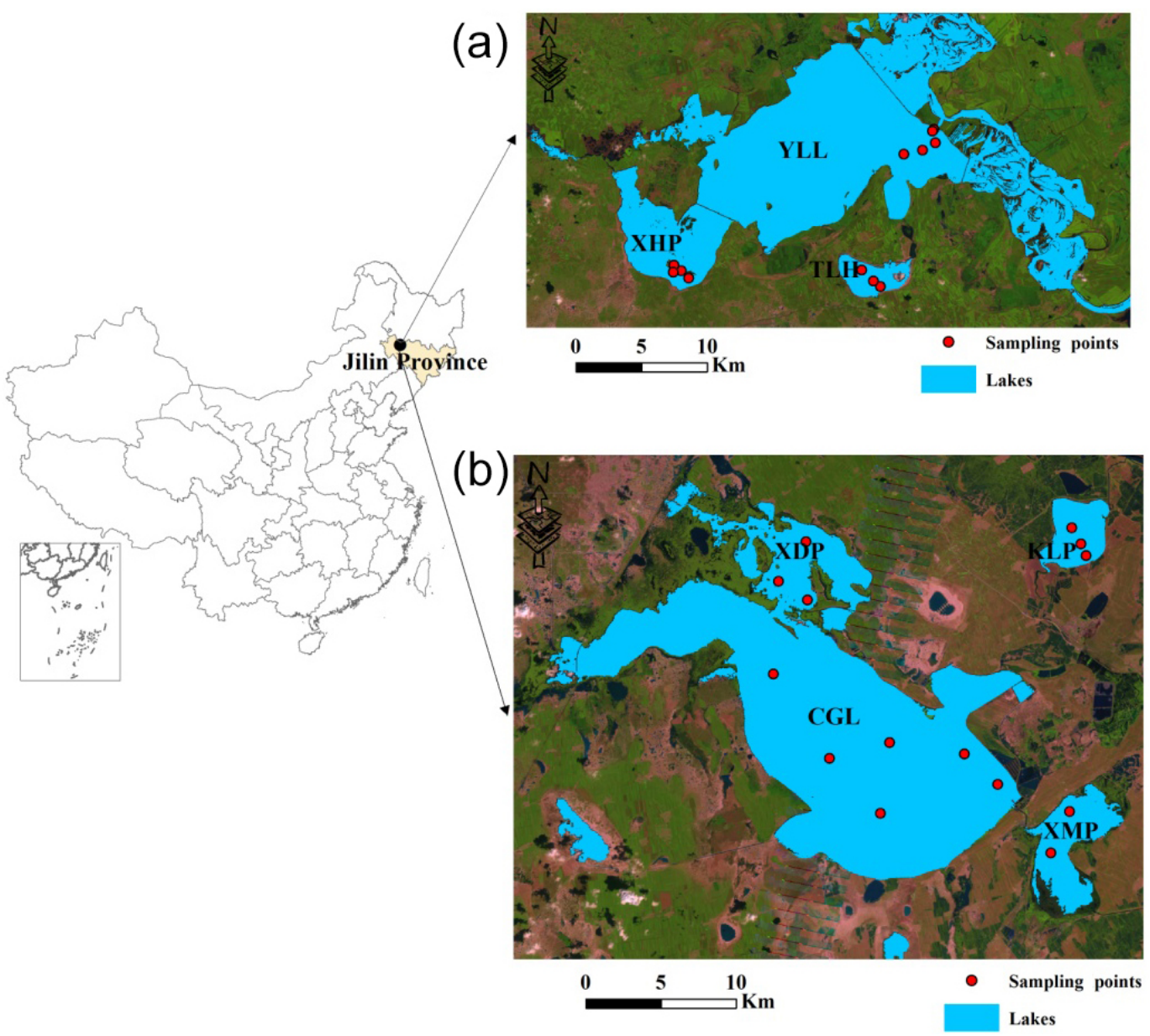

Figure 1. Locations of the water sampling sites for seven lakes in the western part of the province of Jilin, Northeast China. (a) Yueliang lake group: YLL, Yueliang Lake; XHP, Xinhuangpao; TLH, Talahong; (b) Chagan lake group: CGL, Chagan Lake; XDP, Xindianpao; XMP, Xinmiaopao; KLP, Kulipao.

ing values (NaN - "not a number") were inserted in the regions $(\mathrm{Ex}-20 \leqq \mathrm{Em} \leqq \mathrm{Ex}+20$ and $2 \mathrm{Ex}-20 \leqq \mathrm{Em} \leqq 2 \mathrm{Ex}+20$; unit: $\mathrm{nm}$ ) which are significantly influenced by the firstand second-order scattering from the measured spectroscopic data (Hua et al., 2007; Stedmon and Bro, 2008).

To determine the appropriate number of PARAFAC components, the split-half validation procedure was executed to verify whether the model was valid by comparing the emission and excitation loadings from each half (Stedmon and Bro, 2008). Split-half analysis is the most effective method for implementing the PARAFAC models, in which the EEM is randomly divided into four groups of equal size, and then analyzed for two split halves (1-2 and 3-4 half) respectively. If the correct number of components is chosen, the excitation and emission loadings from the two groups should show the same shape and size (Bro, 1997, 1999). The fluorescence intensity of every component was represented by $F_{\max }$ (Raman unit: $\mathrm{nm}^{-1}$ ) (Stedmon and Markager, 2005).

\subsection{Statistical analysis}

Statistical analysis was conducted using the SPSS 16.0 software package (Statistical Program for Social Sciences). Regression and correlation analysis was used to describe the relationship between the CDOM absorption coefficient, DOC concentration, salinity and $F_{\max }$. A model II-ANOVA (analysis of variance) was performed to determine whether the seasonal variability is higher than between-lake variability. The difference is considered to be statistically significant when $p$ values are less than or equal to 0.05 .

\section{Results and discussion}

\subsection{Water quality conditions}

The water quality parameters, i.e., $\mathrm{pH}$, salinity, and turbidity, for the 67 water samples collected from June 2013 to April 2014 in the western part of Jilin are displayed in Table 1. 
Table 1. Mean value of water quality parameters from June 2013 to April 2014. Turb denotes water turbidity; $N$ denotes sampling numbers.

\begin{tabular}{lcccc}
\hline Sampling season & pH & Salinity & Turb (NTU) & $N$ \\
\hline Jun 2013 & 8.54 & 0.40 & $166.20 \pm 108.73$ & 15 \\
Aug 2013 & 8.63 & 0.37 & $63.13 \pm 31.21$ & 13 \\
Feb 2014 & 8.35 & 0.70 & $21.33 \pm 15.87$ & 17 \\
Apr 2014 & 8.67 & 0.43 & $22.24 \pm 16.42$ & 22 \\
\hline All & 8.55 & 0.48 & $62.18 \pm 79.07$ & 67 \\
\hline
\end{tabular}

When the set of samples from various field trips was pooled together, the waters had high $\mathrm{pH}$ values and high salt contents. The highest salinity was present when the lakes were frozen in February 2014, whereas relatively constant values (around 0.40) were exhibited in the other three seasons. In addition, the waterbodies were highly turbid. The highest turbidity was present in June 2013, and then reduced in August 2013, and the lowest value was recorded in February 2014. Compared with February 2014, the turbidity had almost no change in April 2014 (Table 1).

\subsection{EEM characterization of CDOM}

Based on the EEM "peak picking" technique, the key fluorescence peaks can be observed in 67 water samples: two humic-like and two protein-like substances (Coble, 1996; Stedmon et al., 2003). The humic-like components are the mixture of the humic-like acids of aromatic and aliphatic compounds from terrestrial substances, and aquatic humiclike substances of phytoplankton origin. With respect to the protein-like components (i.e., tyrosine-like and tryptophanlike substances), they mainly consist of dissolved amino acids. As an example, Fig. S1 in the Supplement displays the EEMs of samples from Lake Xindianpao in different seasons. The peaks comprise two humic-like fluorescence peaks: one in the ultraviolet range $(\mathrm{Ex} / \mathrm{Em}=220-240 / 410-430 \mathrm{~nm})$ and the other in the visible range $(\mathrm{Ex} / \mathrm{Em}=300-340 / 410$ $450 \mathrm{~nm}$ ); and protein-like fluorescence peaks: tyrosine-like $(\mathrm{Ex} / \mathrm{Em}=210-230,270-280 / 310-330 \mathrm{~nm})$ and tryptophanlike $(E x / E m=220-230,280-300 / 350-370 \mathrm{~nm})$.

In our study, four separate fluorescent components (Fig. 2a-d) and the excitation and emission loadings (e-h) of the four components identified by EEM-PARAFAC are summarized in Fig. 2 and Table 2. The first fluorescent component $(\mathrm{C} 1)$ was a biological degradation humic-like component comparable to humic-like peaks ( $\mathrm{M}$ and $\mathrm{N}$ ) in marine and in phytoplankton degradation experiments for inland waters (Coble, 1996; Zhang et al., 2009). Component 2 was consistent with the humic-like peaks (A and C) defined by Coble (1996). Component 3 resembles the tryptophan-like (T) component as found by Baker et al. (2004) and Hudson et al. (2007). Component 4 is likely related to the tyrosine-like
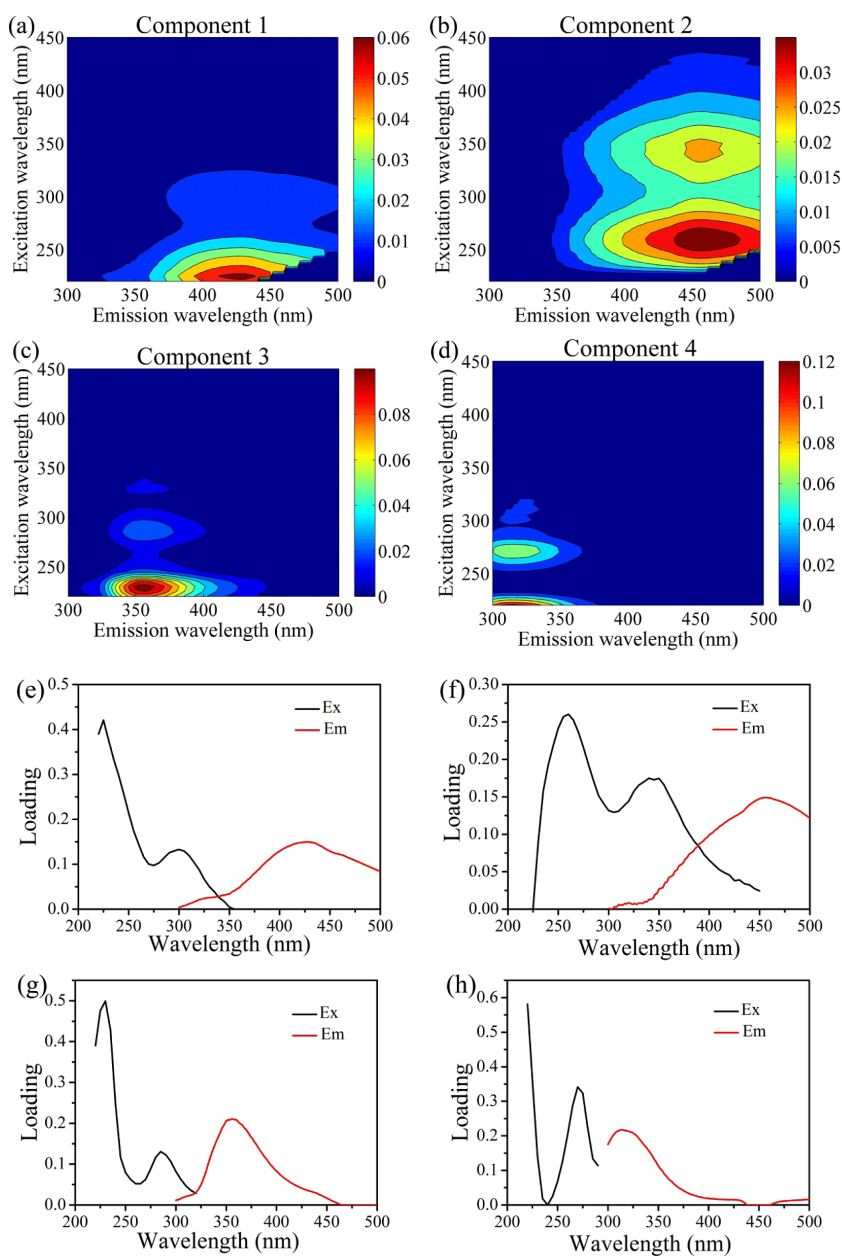

Figure 2. The PARAFAC modeling output shows the contour plots of the four PARAFAC fluorescent components (a-d) and excitation (black) and emission (red) loadings (e-h) of each component. Fluorescence is in Raman units: $\mathrm{nm}^{-1}$.

component (B) (Hudson et al., 2007). Components 3 and 4 represent autochthonous semi-labile CDOM associated with bacteria activity and phytoplankton degradation (Borisover et al., 2009; Stedmon et al., 2003). In particular, there was a shoulder (i.e., deflection but not peak) at the excitation wavelength $310-330 \mathrm{~nm}$ in component 4 and $330-340 \mathrm{~nm}$ in component 3, which may be due to the residual Raman peaks in some water samples (Fig. 2c-d). In this study, not all of the four components were present in all of the samples.

\subsection{Temporal distribution of PARAFAC components}

These fresh and brackish water in Jilin in Northeast China are endowed with similar geological, hydrological and climatic settings; thus it is presumed that similar processes may control the CDOM components. When a model II-ANOVA using season and lake as random effect factors was performed, it shows that the seasonal variability $\left(F>F_{\text {crit }}, p<0.05\right)$ is higher than between-lake variability. Therefore, the water 
Table 2. Positions of the fluorescence maximum peaks of the four components identified by PARAFAC modeling in the present study compared with those previously identified. Secondary excitation maxima are given in brackets.

\begin{tabular}{|c|c|c|c|c|c|}
\hline $\begin{array}{l}\text { Component } \\
\text { no. }\end{array}$ & $\begin{array}{l}\mathrm{Ex}_{\max } \\
(\mathrm{nm})\end{array}$ & $\begin{array}{l}\mathrm{Em}_{\max } \\
(\mathrm{nm})\end{array}$ & $\begin{array}{l}\text { Description and } \\
\text { source }\end{array}$ & $\begin{array}{l}\text { Components } \\
\text { (Coble and Zhang) }\end{array}$ & $\begin{array}{l}\text { Components } \\
\text { (Stedmon and Markager) }\end{array}$ \\
\hline $\mathrm{C} 1$ & $230(300)$ & 425 & Marine humic-like (phytoplankton degradation) & M & 6 \\
\hline $\mathrm{C} 2$ & $255(350)$ & 460 & Terrestrial humic-like & $\mathrm{A}$ and $\mathrm{C}$ & 1 and 4 \\
\hline $\mathrm{C} 3$ & $225(290)$ & 360 & Autochthonous tryptophan-like & $\mathrm{T}$ & \\
\hline $\mathrm{C} 4$ & $220(275)$ & 320 & Autochthonous tyrosine-like & $\mathrm{B}$ & 8 \\
\hline
\end{tabular}

Fluorescence peaks were named as Coble and Zhang components by Coble et al. (1996, 1998) and Zhang et al. (2010, 2011), while as Stedmon and Markager components by Stedmon and Markager (2005).

samples from different lakes for every season were pooled together in order to study the seasonal variation of the fluorescent components. As shown in Fig. 3a, the average fluorescence intensity of the four components had seasonal variation. When all the water samples in different seasons were pooled together, the average value of total fluorescence intensity was $2.05 \pm 0.93 \mathrm{~nm}^{-1}$, corresponding to the intensities of $0.71 \pm 0.32(\mathrm{C} 1), 0.33 \pm 0.11(\mathrm{C} 2), 0.50 \pm 0.24(\mathrm{C} 3)$ and $0.51 \pm 0.26(\mathrm{C} 4) \mathrm{nm}^{-1}$ for different components. These results can demonstrate that the fluorescence intensity was dominated by $\mathrm{C} 1$, implying most of the CDOM for the seven inland lakes originated from the degradation of phytoplankton and microorganisms. The protein-like components ( $\mathrm{C} 3$ and $\mathrm{C} 4$ ), related to bioavailability and microbial activity of CDOM, had almost the same magnitude. In all four seasons, the fluorescent component $\mathrm{C} 2$, which was terrestrially imported to waterbodies, contributed less to total fluorescence than the other three. The total fluorescence intensity differed under seasonal variation, varying from $2.54 \pm 0.68 \mathrm{~nm}^{-1}$ in June to $1.93 \pm 0.70 \mathrm{~nm}^{-1}$ in August 2013, and then increased to $2.34 \pm 0.92 \mathrm{~nm}^{-1}$ in February and reduced to the lowest intensity of $1.57 \pm 0.55 \mathrm{~nm}^{-1}$ in April 2014 (Fig. 3c). The intensities of four fluorescent components (i.e., $0.75 \pm 0.17$ (C1), $0.32 \pm 0.06(\mathrm{C} 2), 0.69 \pm 0.24$ (C3) and $0.77 \pm 0.20$ (C4) $\mathrm{nm}^{-1}$ ) (Fig. 3d) from the samples collected in June 2013 exhibited similar trends to that for the pooled data set. These values were higher than the seasonal average except C2 $\left(0.32 \pm 0.06 \mathrm{~nm}^{-1}\right)$. This can be explained by enhanced activities from plant degradation and microbial activities, but fewer terrestrial substances were imported to the waterbodies in June; therefore, the fluorescence intensity of $\mathrm{C} 2$ was lower than the seasonal average. Compared to the fluorescence intensity in June, the three fluorescence intensities $(0.65 \pm 0.14(\mathrm{C} 1), 0.33 \pm 0.16(\mathrm{C} 3)$ and $0.52 \pm 0.36$ (C4) $\mathrm{nm}^{-1}$ ) from the samples collected in August 2013 were reduced, but an increased value was recorded for $\mathrm{C} 2$ $\left(0.42 \pm 0.05 \mathrm{~nm}^{-1}\right)$ (Fig. 3d). Particularly, the fluorescence intensities of two protein-like components showed an obvious difference. This can be attributed to substantially increased precipitation up to $180 \mathrm{~mm}$ in July from June to August 2013 (Fig. 3b); therefore, floods occurred when rainfall continued to increase in August. Gradually, DOM contained in terrestrial CDOM was flushed by rainfall to the lakes; therefore, the $\mathrm{C} 2\left(0.42 \pm 0.05 \mathrm{~nm}^{-1}\right)$ fluorescence intensity became higher. In accordance with Cheng et al. (2010), the rainwater CDOM for this study was largely characterized by protein-like components (Cheng et al., 2010). The fluorescence intensity of the rainwater CDOM was very weak, and the rainwater CDOM also had a much lower humic-like concentration (Fig. S2b). The intensities of the other three components decreased because of dilution resulting from heavy rain and relatively weak microbial decomposition of plants.

The highest $\mathrm{C} 1\left(1.02 \pm 0.38 \mathrm{~nm}^{-1}\right)$, presented in February 2014 , and the $\mathrm{C} 2\left(0.39 \pm 0.12 \mathrm{~nm}^{-1}\right)$ intensity remained almost the same as that in August 2013. However, the proteinlike components indicated that the C3 $\left(0.57 \pm 0.25 \mathrm{~nm}^{-1}\right)$ intensity was higher than the $\mathrm{C} 4\left(0.35 \pm 0.17 \mathrm{~nm}^{-1}\right)$ intensity, which was opposite to the results from other months (Fig. 3d). In cold winters, the surface waters formed a thick layer of ice covering the lake waters. Because the ice cover reduced light penetration and restricted gas exchange between the underlying water and atmosphere, vigorous biological activity in the lakes would be reduced at low temperature and low light level (Thomas, 1983; Uusikiv et al., 2010; Wharton Jr., et al., 1993). Although the biological activity was very weak, there could still be a bit of production of $\mathrm{C} 1$ and $\mathrm{C} 3$ in lake water. Also, dissolved materials were left in the underlying surface waters and little terrestrial matter was imported to the lakes once covered by ice (Stedmon et al., 2007). Therefore, the $\mathrm{C} 1$ and $\mathrm{C} 3$ in the water of the lakes beneath the ice layers would have been produced and accumulated simultaneously, whereas the $\mathrm{C} 2$ remained the same. Obviously, the fluorescence intensity of component 1 reached the highest value for the winter samples. As shown in Fig. S2a, another striking feature for the winter samples was that the fluorescence of CDOM in the ice was dominated by the tyrosine-like $\mathrm{C} 4$ component, which is consistent with the findings of Barker et al. $(2009,2013)$ and Stedmon et al. (2007). It showed that the C4 component was left in the ice cover when the lakes were frozen. Therefore, it is not surprising that the intensity of component $\mathrm{C} 4$ for water beneath ice layers was reduced and the concentrated $\mathrm{C} 3$ showed a much higher fluorescence intensity. In April 2014, the intensities of four fluorescent compo- 

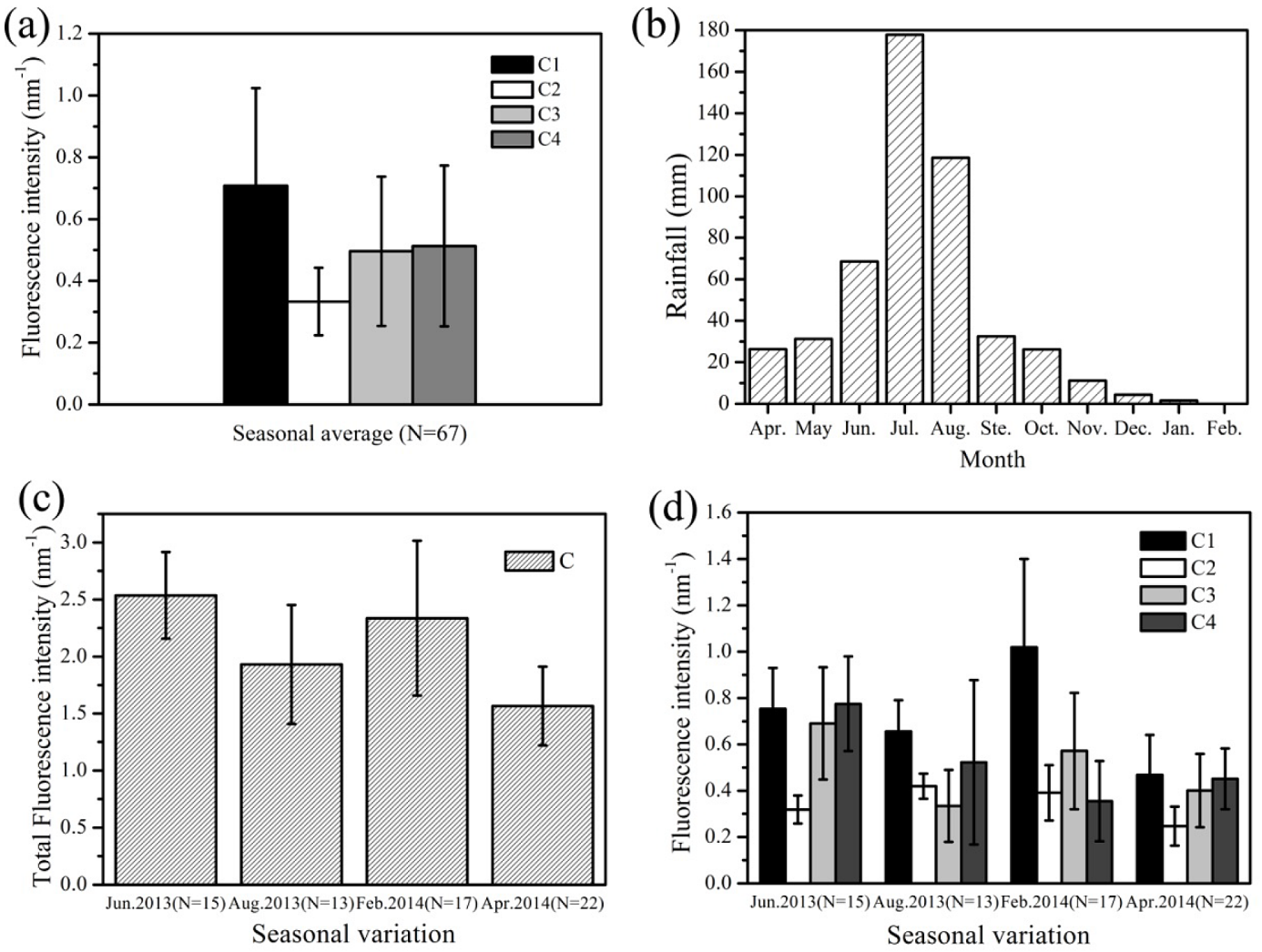

Figure 3. (a) Seasonal average of $F_{\max }$ for EEM-PARAFAC components (C1, C2, C3 and C4) for lakes in the western part of Jilin; (b) monthly variation of rainfall for the lakes in the western part of Jilin from April 2013 to February 2014; (c) seasonal variation of the total fluorescence intensity in different seasons; (d) seasonal variation of the four EEM-PARAFAC components in different seasons. The error bars represent 1 standard deviation.

nents $(0.47 \pm 0.17(\mathrm{C} 1), 0.25 \pm 0.08(\mathrm{C} 2), 0.40 \pm 0.16(\mathrm{C} 3)$ and $0.45 \pm 0.13(\mathrm{C} 4) \mathrm{nm}^{-1}$ ) (Fig. 3d) exhibited similar seasonal trends, though these values were much lower than the average. Our interpretation is that the ice CDOM was characterized by the tyrosine-like component (C4) (Fig. S2a), and the fluorescence intensity of $\mathrm{C} 4$ contributed by the ice meltwater was very weak. However, the underlying lake CDOM included both humic-like ( $\mathrm{C} 1$ and $\mathrm{C} 2)$ and protein-like (C3 or C4) components. When the ice in the lakes melted into water during warming weather and biological degradation, and human activity was weak, the lake CDOM was diluted by the ice meltwater and the fluorescence intensity reached its lowest value in early spring.

\subsection{CDOM vs. EEM-PARAFAC-extracted components}

The concentration of DOC, CDOM absorption coefficients and the slope ratio $S_{\mathrm{R}}$ are shown in Table 3. The DOC concentrations ranged from 835.83 to $7345.83 \mu \mathrm{mol} \mathrm{L}^{-1}$, with an average value of $3133.05 \pm 1504.14 \mu \mathrm{mol} \mathrm{L}^{-1}$ during the period from June 2013 to April 2014, demonstrating seasonal dynamics that can be attributed to hydrological, climatic and landscape variations (Song et al., 2013). The highest aver- age DOC concentration $\left(4587.03 \pm 1666.83 \mu \mathrm{mol} \mathrm{L}^{-1}\right)$ was present in February 2014 (ice-covered period); whereas relatively constant values of approximate $2500 \mu \mathrm{mol} \mathrm{L}^{-1}$ were observed in the ice-free season. The relative high DOC concentration in the ice-free season was caused by the evapocondensed effect due to the prolonged sunshine duration for the lakes in the Songnen Plain. The higher DOC concentration in winter can be attributed to the accumulated DOC left in the liquid phase when ice formation took place, resulting in the higher DOC concentration in the underlying water (unpublished material). Generally, the absorption coefficient $a(350)$ is used as a proxy for characterizing CDOM concentration (Guo et al., 2010; Zhang et al., 2011); $a(280)$ is related to DOC biodegradation (McDowell et al., 2006), and $a(254)$ can be used to characterize the optical properties of DOC aromaticity (Jaffé et al., 2004; Weishaar et al., 2003). The highest averaged CDOM absorption coefficients, $a(350)$, $a(280)$ and $a(254)$, were also present in February 2014, corresponding to the highest DOC concentration. The $S_{\mathrm{R}}$ values of the two wavelength ranges (275-295 over 350-400 nm) were used to represent DOM molecular weight (Helms et al., 2008). The lowest mean of $S_{\mathrm{R}}$ was present in August 2013, suggesting that the relatively weak microbial decomposition 

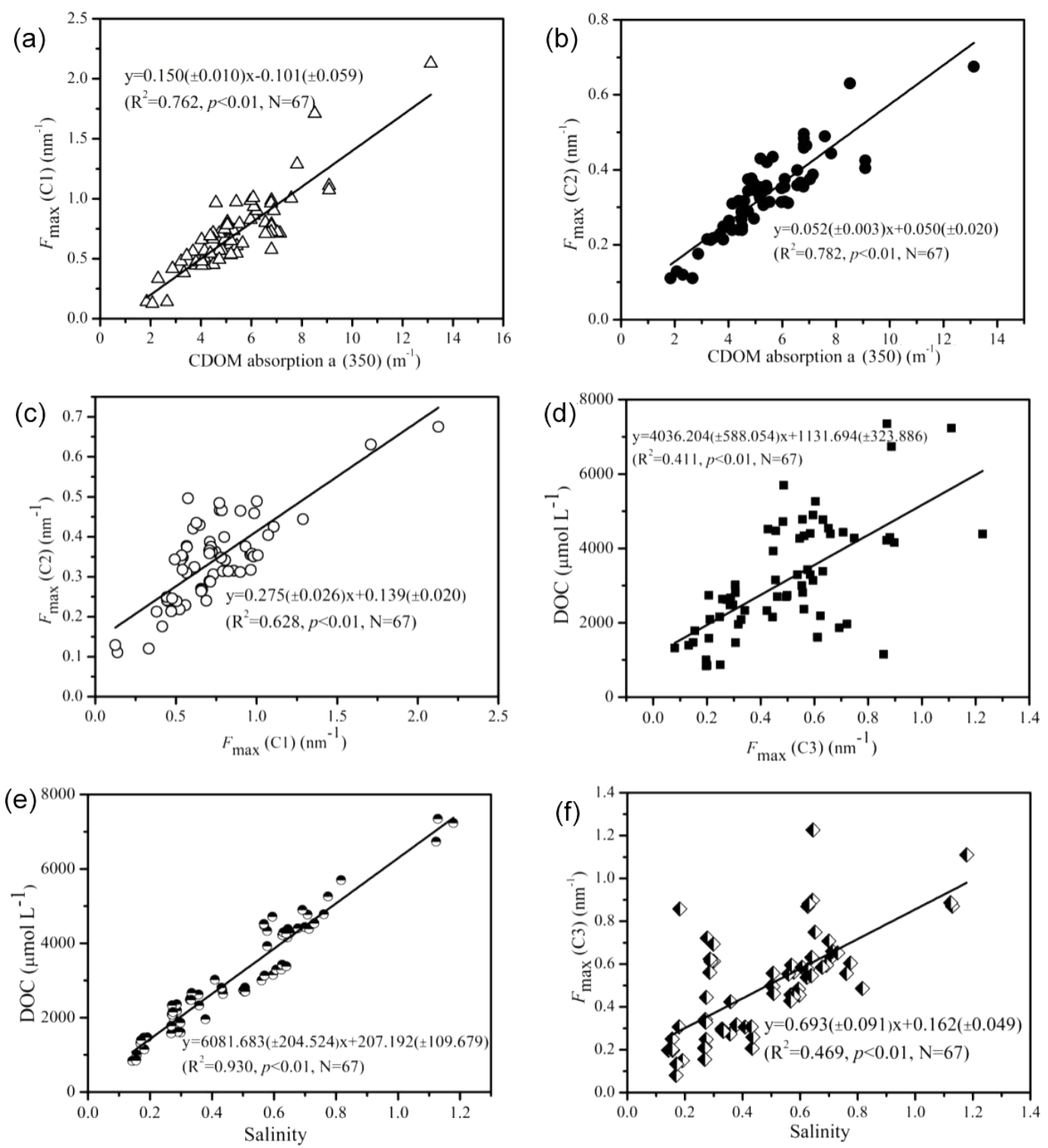

Figure 4. Relationships between CDOM absorption coefficient $a(350)$ with (a) $F_{\max }(\mathrm{C} 1)$, (b) with $F_{\max }(\mathrm{C} 2)$, (c) peak $F_{\max }(\mathrm{C} 1)$ vs. $F_{\max }$ (C2), (d) peak $F_{\max }(\mathrm{C} 3)$ vs. DOC, (e) salinity vs. DOC, (f) salinity vs. $F_{\max }(\mathrm{C} 3)$.

of plants and lots of terrestrially imported substances through rainwash resulted in the higher average molecular weight of DOC.

When the whole data set $(N=67)$ was pooled together, there were significantly positive linear relationships between $a(254), a(280), a(350)$ and $F_{\max }$ for two humic-like components ( $\mathrm{C} 1$ and $\mathrm{C} 2)$, respectively, but mostly, such correlations were not observed for the protein-like components (Fig. 4a and b, Table 3). These results were in accordance with previous investigations (Zhang et al., 2010, 2011). Components 1 and 2 were strongly linearly correlated with each other $\left(R^{2}=0.628\right)$ (Fig. $\left.4 \mathrm{c}\right)$, indicating that the concentrations of the two humic-like components were controlled by common sources (Baker and Spencer, 2004). There was a weak relationship $\left(R^{2}=0.051\right)$ between the protein-like components (C3 and $\mathrm{C} 4$ ), possibly because of a complex origin of CDOM such as rainfall in summer, ice in winter and organic pollutants derived from domestic, agricultural and industrial sewerage, which represent the complex origins of CDOM. However, there was almost no correlation between the humic-like and protein-like components. The linkage of a fluorescence signal to DOC was very complicated because of the seasonal impacts, i.e., increased rainfall, algal blooms and ice cover, which affect the DOC concentration. Due to both steady and labile CDOM fluorescent components in DOC, the fluorescent signal changed with the ratio of fluo- 
Table 3. Mean values of DOC concentration and CDOM absorption coefficients groups in different seasons. $S_{\mathrm{R}}$ : the slope ratio of

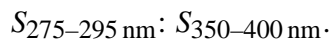

\begin{tabular}{lcccccc}
\hline Sampling season & $a(254) \mathrm{m}^{-1}$ & $a(280) \mathrm{m}^{-1}$ & $a(350) \mathrm{m}^{-1}$ & $S_{\mathrm{R}}$ & DOC $\mu \mathrm{mol} \mathrm{L}$ & $N$ \\
\hline Jun 2013 & $38.39 \pm 9.23$ & $25.98 \pm 6.38$ & $5.73 \pm 1.68$ & $1.29 \pm 0.16$ & $2653.08 \pm 1222.14$ & 15 \\
Aug 2013 & $29.71 \pm 4.73$ & $19.36 \pm 2.91$ & $5.82 \pm 0.81$ & $0.96 \pm 0.22$ & $2735.99 \pm 1231.61$ & 13 \\
Feb 2014 & $52.88 \pm 18.13$ & $34.62 \pm 11.54$ & $6.36 \pm 2.17$ & $1.18 \pm 0.11$ & $4587.03 \pm 1666.83$ & 17 \\
Apr 2014 & $34.43 \pm 11.38$ & $22.45 \pm 7.36$ & $4.17 \pm 1.49$ & $1.32 \pm 0.13$ & $2571.38 \pm 909.47$ & 22 \\
\hline All & $39.08 \pm 14.73$ & $25.73 \pm 9.58$ & $5.40 \pm 1.84$ & $1.21 \pm 0.20$ & $3133.05 \pm 1504.14$ & 67 \\
\hline
\end{tabular}

Table 4. Correlation coefficients $(R)$ and significance levels $(p)$ of the linear relationships between CDOM absorption, DOC, salinity and fluorescent components.

\begin{tabular}{llllllllll}
\hline & $a(254)$ & $a(280)$ & $a(350)$ & DOC & Salinity & C1 & C2 & C3 & C4 \\
\hline DOC & $0.711^{* *}$ & $0.646^{* *}$ & $0.294^{*}$ & $1.000^{* *}$ & & & & & \\
Salinity & $0.650^{* *}$ & $0.579^{* *}$ & 0.159 & $0.965^{* *}$ & $1.000^{* *}$ & & & & \\
C1 & $0.850^{* *}$ & $0.875^{* *}$ & $0.873^{* *}$ & $0.496^{* *}$ & $0.383^{* *}$ & $1.000^{* *}$ & & & \\
C2 & $0.677^{* *}$ & $0.686^{* *}$ & $0.885^{* *}$ & $0.414^{* *}$ & $0.270^{*}$ & $0.796^{* *}$ & $1.000^{* *}$ & & \\
C3 & $0.452^{* *}$ & $0.417^{* *}$ & 0.134 & $0.648^{* *}$ & $0.685^{* *}$ & $0.267^{*}$ & 0.103 & $1.000^{* *}$ & \\
C4 & -0.040 & -0.016 & 0.078 & -0.101 & 0.135 & 0.084 & 0.069 & 0.225 & $1.000^{* *}$ \\
\hline
\end{tabular}

${ }^{*} p<0.05$ level; ${ }^{* *} p<0.01$ level.

rescent and non-fluorescent CDOM components (Henderson et al., 2009). A weak relationship $\left(R^{2}=0.411\right)$ (Fig. 4d) was found between DOC and component 3, likely from the decay of plants through microbial activity or the pollution from human and animal waste.

Different from the findings by Yamashita et al. (2008) for ocean water, this study did not find obvious correlation between salinity and EEM-PARAFAC-extracted components, with the exception of C3 $\left(R^{2}=0.469\right)$ (Table 4 and Fig. $4 \mathrm{f}$ ). The most important finding for the water samples collected in different seasons from the Songnen Plain is a significant relationship $\left(R^{2}=0.930\right)$ between salinity and DOC (Fig. 4e). This is because DOC is evapo-condensed from spring to autumn and freeze-accumulated in winter in the semiarid region. A prolonged sunshine duration can result in an evapocondensed DOC concentration in the ice-free season. On the other hand, the DOC accumulates when the lakes freeze in winter, leaving DOC in the liquid phase.

\section{Conclusions}

A model II-ANOVA using season and lake as random effect factors shows that the seasonal variability $\left(F>F_{\text {crit }}\right.$, $p<0.05)$ is higher than between-lake variability. In this study, the application of EEM-PARAFAC to characterize four fluorescent components under seasonal variation in CDOM was presented with 67 water samples collected from June 2013 to April 2014 in the semiarid region of the Songnen Plain. Two humic-like components and protein-like components were identified using the PARAFAC modeling. The average fluorescence intensity of the four components differed under seasonal variation from June 2013 to April 2014. The highest C1 $1.02 \mathrm{~nm}^{-1}$ was presented in February 2014, probably due to the condensed CDOM caused by ice formation in winter. Especially in summer, when rainfall occurs, and in winter when water is frozen, the fluorescence intensity is dominated by tyrosine-like components in rain and ice meltwater. Components 1 and 2 exhibited a strong linear correlation $\left(R^{2}=0.628\right)$. There were significantly positive linear relationships between $F_{\max }$ and CDOM absorption coefficient $a(254)\left(R^{2}=0.72,0.46, p<0.01\right), a(280)$ $\left(R^{2}=0.77,0.47, p<0.01\right)$ and $a(350)\left(R^{2}=0.76,0.78\right.$, $p<0.01)$ for two humic-like components $(\mathrm{C} 1$ and $\mathrm{C} 2)$, respectively. A weak relationship $\left(R^{2}=0.411\right)$ was found between DOC and component 3 from the decay of plants through microbial activity or the pollution from human and animal waste. However, almost no obvious correlation was found between salinity and EEM-PARAFAC-extracted components, except $\mathrm{C} 3\left(R^{2}=0.469\right)$, though the correlation was not as strong as with DOC concentration. Most importantly, a significant relationship $\left(R^{2}=0.930\right)$ was found between salinity and DOC. In order to understand the biogeochemical effects on the aquatic ecosystem, further study is required to identify the source of CDOM and assess physi$\mathrm{cal} / \mathrm{chemical}$, bioavailable and photoreactive transformation in various lakes with larger saline gradients in the semiarid region of Northeast China.

The Supplement related to this article is available online at doi:10.5194/bg-13-1635-2016-supplement. 
Acknowledgements. The research was jointly supported by the "One Hundred Talents" program from Chinese Academy of Sciences and the National Natural Science Foundation of China (no. 41471290). The authors thank Zhi Ding, Ying Guan, Lei Liu and Ming Wang for their persistent assistance with both field sampling and laboratory analysis.

Edited by: G. Herndl

\section{References}

Aiken, G. R., McKnight, D. M., Thorn, K. A., and Thurman, E. M.: Isolation of hydrophobic organic-acids from water using nonionic macro porous resins, Org. Geochem., 18, 567-573, 1992.

Andersen, C. M. and Bro, R.: Practical aspects of PARAFAC modeling of fluorescence excitation-emission data, J. Chemometr., 17, 200-215, 2003.

Andersson, C. A. and Bro, R.: The N-way Toolbox for MATLAB, Chemometr. Intell. Lab., 52, 1-4, 2000.

APHA/AWWA/WEF: Standard Methods for the Examination of Water and Wastewater, Washington, DC, American Public Health Associstion, 1998.

Babin, M., Stramski, D., Ferrari, G. M., Claustre, H., Bricaud, A., Obolensky, G., and Hoepffner, N.: Variations in the light absorption coefficients of phytoplankton, nonalgal particles, and dissolved organic matter in coastal waters around Europe, J. Geophys. Res., 108, 3211-3230, 2003.

Baker, A. and Spencer, R. G. M.: Characterization of dissolved organic matter from source to sea using fluorescence and absorbance spectroscopy, Sci. Total Environ., 333, 217-232, 2004.

Baker, A., Ward, D., Lieten, Shakti H., Periera, R., Simpson, Ellie C., and Slater, M.: Measurement of protein-like fluorescence in river and waste water using a handheld spectrophotometer, Water Res., 38, 2934-2938, 2004.

Barker, J. D., Sharp, M. J., Fitzsimons, S. J., and Turner, R. J.: Abundance and dynamics of dissolved organic carbon in glacier systems, Arct. Antarct. Alp. Res., 38, 163-172, 2006.

Barker, J. D., Sharp, M. J., and Turner, R. J.: Using synchronous fluorescence spectroscopy and principal components analysis to monitor dissolved organic matter dynamics in a glacier system, Hydrol. Process., 23, 1487-1500, 2009.

Barker, J. D., Klassen, J. L., Sharp, M. J., Fitzsimons, S. J., and Turner, R. J.: Detecting biogeochemical activity in basal ice using fluorescence spectroscopy, Ann. Glaciol., 51, 47-55, 2010.

Barker, J. D., Dubnick, A., Lyons, W. B., and Chin, Y. P.: Changes in Dissolved Organic Matter (DOM) Fluorescence in Proglacial Antarctic Streams, Arct. Antarct. Alp. Res., 45, 305-317, 2013.

Borisover, M., Laor, Y., Parparov, A., Bukhanovsky, N., and Lado, M.: Spatial and seasonal patterns of fluorescent organic matter in Lake Kinneret (Sea of Galilee) and its catchment basin, Water Res., 43, 3104-3116, 2009.

Bricaud, A., Babin, M., Morel, A., and Claustre, H.: Variability in the chlorophyll-specific absorption coefficients of natural phytoplankton: Analysis and parameterization, J. Geophys. Res., 100, 13321-13332, 1995.

Bro, R.: PARAFAC tutorial and applications, Chemometr. Intell. Lab., 38, 149-171, 1997.
Bro, R.: Exploratory study of sugar production using fluorescence spectroscopy and multi-way analysis, Chemometr. Intell. Lab., 46, 133-147, 1999.

Cheng, Y. Y., Guo, W. D., Long, A. M., and Chen, S. Y.: Study on optical characteristic of chromophoric dissolved organic matter in rainwater by fluorescence excitation-emission matrix and absorbance spectroscope, Spectrosc. Spect. Anal., 30, 2413-2416, 2010 (in Chinese).

Coble, P. G.: Characterization of marine and terrestrial DOM in seawater using excitation-emission matrix spectroscopy, Mar. Chem., 51, 325-346, 1996.

Coble, P. G.: Marine optical biogeochemistry: the chemistry of ocean color, Chem. Rev., 107, 402-418, 2007.

Coble, P. G., Del Castillo, C. E., and Avril, B.: Distribution and optical of CDOM in the Arabian Sea during the 1995 Southwest Monsoon, Deep-Sea Res. Pt. II, 45, 2195-2223, 1998.

Cory, R. M. and McKnight, D. M.: Fluorescence spectroscopy reveals ubiquitous presence of oxidized and reduced quinines in dissolved organic matter, Environ. Sci. Technol., 39, 8142-8149, 2005.

Del Castillo, C. E., Coble, P. G., Morell, J. M., Lopez, J. M., and Corredor, J. E.: Analysis of the optical properties of the Orinoco River plume by absorption and fluorescence spectroscopy, Mar. Chem., 66, 35-51, 1999.

Duarte, C. M., Montes, C., Cole, J. J., Striegl, R. G., Melackand, J., and Downing, J. A.: $\mathrm{CO}_{2}$ emissions from saline lakes: Aglobal estimate of asurprisingly large flux, J. Geophys. Res.-Biogeo., 113, G04041, doi:10.1029/2007JG000637, 2008.

Fellman, J. B., Hood, E., and Spencer, R. G. M.: Fluorescence spectroscopy opens new windows into dissolved organic matter dynamics in freshwater ecosystems: A review, Limnol. Oceanogr., 55, 2452-2462, 2010.

Guo, W. D., Xu, J., Wang, J. P., Wen, Y. G., Zhou, J. F., and Yan, Y. C.: Characterization of dissolved organic matter in urban sewage using excitation emission matrix fluorescence spectroscopy and parallel factor analysis, J. Environ. Sci., 22, 1728-1734, 2010.

Helms, J. R., Stubbins, A., Ritchie, J. D., Minor, E. C., Kieber, D. J., and Mopper, K.: Absorption spectral slopes and slope ratios as indicators of molecular weight, source, and photo bleaching of chromophoric dissolved organic matter, Limnol. Oceanogr., 53, 955-969, 2008.

Henderson, R. K., Baker, A., Murphy, K. R., Hambly, A., Stuetz, R. M., and Khan, S. J.: Fluoresence as a potential monitoring tool for recycled water system: A review, Water Res., 43, 863-881, 2009.

Hua, B., Dolan, F., Mcghee, C., Clevenger, T. E., and Deng, B. L.: Water-source characterization and classification with fluorescence EEM spectroscopy: PARAFAC analysis, Int. J. Environ. An. Ch., 87, 135-147, 2007.

Hudson, N., Baker, A., and Reynolds, D.: Fluorescence analysis of dissolved organic matter in natural, waste and polluted waters a review, River Res. Appl., 23, 631-649, 2007.

Jaffé, R., Boyer, J. N., Lu, X., Maie, N., Yang, C., Scully, N. M., and Mock, S.: Source characterization of dissolved organic matter in subtropical mangrove-dominated estuary by fluorescence analysis, Mar. Chem., 84, 195-210, 2004.

Larsson, T., Wedborg, M., and Turner, D.: Correction of inner-filter effect in fluorescence excitation-emission matrix spectrometry using Raman scatter, Anal. Chim. Acta., 583, 357-363, 2007. 
Lawaetz, A. J. and Stedmon, C. A.: Fluorescence Intensity Calibration Using the Raman Scatter Peak of Water, Appl. Spectrosc., 63, 936-940, 2009.

Mayer, L. M., Schick, L. L., and Loder, T. C.: Dissolved protein fluorescence in two Maine estuaries, Mar. Chem., 64, 171-179, 1999.

McDowell, W. H., Zsolnay, A., Aikenhead-Peterson, J. A., Gregorich, E. G., Jones, D. L., Jödermann, D., Kalbitz, K., Marschner, B., and Schwesig, D.: A comparison of methods to determine the biodegradable dissolved organic carbon from different terrestrial sources, Soil Biol. Biochem., 38, 1933-1942, 2006.

McKnight, D. M., Boyer, E. W., Westerhoff, P. K., Doran, P. T., Kulbe, T., and Andersen, D. T.: Spectrofluorometriccharacterization of dissolved organic matter for indication of precursor organic material and aromaticity, Limnol. Oceanogr., 46, 38-48, 2001.

Song, C. C., Wang, L. L., Guo, Y. D., Song, Y. Y., Yang, G. S., and Li, Y. C.: Impacts of natural wetland degradation on dissolved carbon dynamics in the Sanjiang Plain, Northeastern China, J. Hydrol., 398, 26-32, 2011.

Song, K. S., Zang, S. Y., Zhao, Y., Li, L., Du, J., Zhang, N. N., Wang, X. D., Shao, T. T., Guan, Y., and Liu, L.: Spatiotemporal characterization of dissolved carbon for inland waters in semi-humid/semi-arid region, China, Hydrol. Earth Syst. Sci., 17, 4269-4281, doi:10.5194/hess-17-4269-2013, 2013.

Spencer, R. G. M., Hernes, P. J., Ruf, R., Baker, A., Dyda, R. Y., Stubbins, A., and Six, J.: Temporal controls on dissolved organic matter and lignin biogeochemistry in apristine tropical river, J. Geophys. Res.-Biogeo., 115, G03013, doi:10.1029/2009JG001180, 2010.

Stedmon, C. A. and Bro, R.: Characterizing dissolved organic matter fluorescence with parallel factor analysis: a tutorial, Limnol. Oceanogr.-Meth., 6, 572-579, 2008.

Stedmon, C. A. and Markager, S.: Tracing the production and degradation of autochthonous fractions of dissolved organic matter by fluorescence analysis, Limnol. Oceanogr., 50, 1415-1426, 2005.

Stedmon, C. A., Markager, S., and Bro, R.: Tracing dissolved organic matter in aquatic environments using a new approach to fluorescence spectroscopy, Mar. Chem., 82, 239-254, 2003.

Stedmon, C. A., Thomas, D. N., Granskog, M., Kaartokallio, H., Papadimitriou, S., and Kuosa, H.: Characteristics of dissolved organic matter in Baltic coastal sea ice: allochthonous or autochthonous origins?, Environ. Sci. Technol., 41, 7273-7279, 2007.

Thomas K. B.: Under Landfast ice, Arctic, 36, 328-340, 1983.

Tranvik, L. J., Downing, J. A., Cotner, J. B., Loiselle, S. A., Striegl, R. G., Ballatore, T. J., Dillon, P., Finlay, K., Fortino, K., Knoll, L. B., Kortelainen, P. L., Kutser, T., Larsen, S., Laurion, I., Leech, D. M., McCallister, S. L., McKnight, D. M., Melack, J. M., Overholt, E., Porter, J. A., Prairie, Y., Renwick, W. H., Roland, F., Sherman, B. S., Schindler, D. W., Sobek, S., Tremblay, A., Vanni, M. J., Verschoor, A. M., Wachenfeldt, E. V., and Weyhenmeyer, G. A.: Lakes and reservoirs as regulators of carbon cycling and climate, Limnol. Oceanogr., 54, 2298-2314, 2009.
Uusikiv, J., Vahatal, A. V., Granskog, M. A., and Sommaruga, R.: Contribution of mycosporine-like amino acids and colored dissolved and particulate matter to sea ice optical properties and ultraviolet attenuation, Limnol. Oceanogr., 55, 703-713, 2010.

UV Talk Letter: https://shimadzu.com.au/uv-talk-letter-volume-10 (last access: 12 March 2016), Volume 10, 2013.

Weishaar, J. L., Aiken, G. R., Bergamaschi, B. A., Farm, M. S., Fujii, R., and Mopper, K.: Evaluation of specific ultraviolet absorbance as an indicator of the chemical composition and reactivity of dissolved organic carbon, Environ. Sci. Technol., 37, 47024708, 2003.

Wharton Jr., R. A., McKay, C. P., Clow, G. D., and Andersen, D. T.: Perennial ice covers and their influence on Antarctic lake ecosystems, Antarct. Res. Ser., 59, 53-70, 1993.

Yamashita, Y.: Assessing the dynamics of dissolved organic matter (DOM) in coastal environments by excitation emission matrix fluorescence and parallel factor analysis (EEM-PARAFAC), Limnol. Oceanogr., 53, 1900-1908, 2008.

Yamashita, Y., Cory, R. M., Nishioka, J., Kuma, K., Tanoue, E., and Jaffé, R.,: Fluorescence characteristics of dissolved organic matter in the deep waters of the Okhotsk Sea and the northwestern North Pacific Ocean, Deep-Sea Res. Pt. II, 57, 1478-1485, 2010.

Zhang, Y. L., VanDijk, M. A., Liu, M. L., Zhu, G. W., and Qin, B. Q.: The contribution of phytoplankton degradation to chromophoric dissolved organic matter (CDOM) in eutrophic shallow lakes: Field and experimental evidence, Water Res., 43, 4685-4697, 2009.

Zhang, Y. L., Zhang, E. L., Yin, Y., VanDijk, M. A., Feng, L. Q., Shi, Z. Q., Liu, M. L., and Qin, B. Q.: Characteristics and sources of chromophoric dissolved organic matter in lakes of the Yungui Plateau, China, differing in trophic state and altitude, Limnol. Oceanogr., 55, 2645-2659, 2010.

Zhang, Y. L., Yin, Y., Feng, L. Q., Zhu, G. W., Shi, Z. Q., Liu, X. H., and Zhang, Y. Z.: Characterizing chromophoric dissolved organic matter in Lake Tianmuhu and its catchment basin using excitation-emission matrix fluorescence and parallel factor analysis, Water Res., 45, 5110-5122, 2011.

Zhang, Y. L., Liu, X. H., Osburn, C. L., Wang, M. Z., Qin, B. Q., and Zhou, Y. Q.: Photo bleaching response of different Source of Chromophoric Dissolved Organic Matter Exposed to Natural Solar Radiation Using Absorption and Excitation-Emission Matrix Spectra, Plos One, 8, e77515, doi:10.1371/journal.pone.0077515, 2013. 